\title{
Excelsior!
}

\section{Inspirational Verse, the Victorian Working-Class Poet, and the Case of Longfellow.}

Even though Ronan was snarling and Noah was sighing and Adam was hesitating, he didn't turn to verify that they were coming. He knew they were. In three different ways, he'd earned them all days or weeks or months before, and when it came to it, they'd all follow him anywhere.

'Excelsior,' said Gansey, and shut the door behind them.

'Excelsior,' Gansey said bleakly.

Blue asked, 'What does that even mean?'

Maggie Stiefvater, from The Raven Boys.

The shades of night were falling fast

As through an Alpine village passed

A youth, who bore, 'mid snow and ice,

A banner with the strange device,

Excelsior!

Henry Wadsworth Longfellow, from 'Excelsior'

In Stiefvater's popular young adult fantasy sequence, The Raven Cycle (2012-2016),

'Excelsior' is a catch-phrase used repeatedly and superstitiously by the protagonist, Richard 
Gansey III, whose quest for a lost Welsh king buried in rural Virginia shapes the four-book narrative. 'Excelsior,' roughly meaning 'ever higher,' was a term popularized in the nineteenth century by Longfellow's eponymous poem, in which a mysterious youth climbs onwards and upwards into the Alps, ignoring various warnings, and is then found frozen to death in the final stanza. For Gansey to cite it at the outset of new adventures or when entering a magical location is entirely appropriate. Like Longfellow's hero, he is on a lonely, self-appointed and grimly determined mission, likely to end in his death. In addition, Gansey's 'Excelsior' is a signifier of his excessive white male privilege. His elite private education, his wealth, his family's standing, are thematically central to the series. That he is familiar with a poem by Longfellow, a highly-educated, cosmopolitan, white male Harvard professor with a love of all things European (while Blue, a working-class woman, is unfamiliar with it) is not at all surprising. 'Excelsior' signals Gansey's resolve to venture into the unknown and strength to keep going in the face of danger and despair. However, since none of the other characters in The Raven Quartet recognize the allusion, referencing Longfellow also signifies something unusual for the twenty-first century; a young American hero who not only knows his poetic canon but is in many ways attuned to perceived nineteenth-century ideals of duty and perseverance.

Longfellow's poetry, as this example suggests, still has a ghostly inspirational presence in contemporary literature. I select this particular instance because it shows how far Longfellow's 'Excelsior' — and indeed our perception of Longfellow — has travelled since the poem's mass circulation in the Victorian period. From being common property, in all the senses of the word 'common', 'Excelsior' is now a symbol of eccentricity and high-class education. From being arguably the popular poet, the poet of the people, Longfellow is now the poet for a privileged few. This article considers Longfellow's vital importance for British working-class poets and readers in the mid-late Victorian period, and suggests that he is the 
single most important contemporary influence on their work, and possibly the second most important literary influence more broadly, after Robert Burns. Yet I also seek to use Longfellow as a means to frame the highly neglected genre of inspirational verse, to offer a brief taxonomy of this genre, and to suggest the complex ways in which it operates, and how it can be deployed for political and indeed radical ends. While 'Excelsior' is hardly a positive poem, since the youth is dead at its close, his motives and his cause a mystery, the term 'Excelsior!' became Victorian shorthand for being inspired to persist against all odds. As the Star of Freedom (formerly the Chartist Northern Star) suggested in 1852:

'Excelsior' is the battle-anthem of all who combat for freedom and right! Excelsior, exclaims the martyr, even though friends should fail, and the night gather darkly around. 'Excelsior', shouts the patriot, though the scaffold loom ominously in his way, though the axe gleam, and his next step be the death-plunge into the grave. ${ }^{2}$ From the Excelsior manuscript magazine of an unknown mutual improvement group in Liverpool in the 1860s, to the "Excelsior" National Association of Tinplate-Makers (mentioned below), to the Southern US textile workers' journal, the Textile Excelsior, 'Excelsior' symbolized this 'onwards and upwards' mentality, for a transatlantic and international audience across the Anglophone world. ${ }^{3}$

Inspirational verse was essential in formulating and popularizing these ideologies of progress and struggle. Though far from unique to the Victorian period, this genre found an important home in the popular newspaper and periodical press of this era, where it was circulated on a mass scale. 'Inspirational' poems, in the definition I offer below, are a key product of the international mass media, since they are designedly applicable across time and space and can be (and often were) readily reprinted and repurposed. Along with love poems, elegy and pastoral, and perhaps exceeding all of these, this strand of inspirational verse is the most frequently found type of poetry in regional newspaper poetry columns. It is also 
probably the single most frequent genre practiced by working-class writers. Yet no critical discussions of inspirational verse exist: the nearest relevant discussions would be studies of hymns and religious verse, particularly in periodicals, or assessments of Victorian poetry's intent to act on mind, heart and will. ${ }^{4}$ This is not surprising, because a core characteristic of inspirational verse is that it aims to sound familiar and unoriginal. Both in terms of content and form, it deliberately eschews individuality, specificity and innovation. Borrowing Christoph Irmscher's characterization of Longfellow, it is 'relentlessly accessible.'(2006, p.67) Unless - like Longfellow's poems - its cultural circulation and influence was so large that it cannot be ignored, it slips under the radar. Yet clearly this kind of poetry was doing significant work in Victorian culture, in terms of its emotional affect, and in helping to shape core concepts of what a poem should be and should do.

In its widest definition, 'inspirational' Victorian poetry might include any poem a reader would recall as an aid in times of trouble, in which case canonical poems such as Tennyson's In Memoriam (1850), or Browning's 'Epilogue' to Asolando (1889), are inspirational verse. Here, I narrow down inspirational verse to what might be called 'communal' inspirational verse (unlike these examples from Tennyson and Browning, it focuses on 'we' and 'us') or indeed inspirational newspaper verse, since the formal characteristics of the poems cited here are that they have short lines and few stanzas, making them eminently suited for the physical spaces of periodical and newspaper columns. The urpoem of this inspirational genre is Longfellow's 'A Psalm of Life', first published in The Voices of the Night (1839) and very widely circulated thereafter:

Tell me not, in mournful numbers,

Life is but an empty dream! -

For the soul is dead that slumbers, And things are not what they seem. 
Life is real! Life is earnest!

And the grave is not its goal;

Dust thou art, to dust returnest,

Was not spoken of the soul.

Not enjoyment, and not sorrow,

Is our destined end and way;

But to act, that each to-morrow

Find us farther than to-day.

In the world's broad field of battle,

In the bivouac of Life,

Be not like dumb, driven cattle!

Be a hero in the strife!

Lives of great men all remind us

We can make our lives sublime,

And, departing, leave behind us

Footprints on the sands of time;

Footprints, that perhaps another,

Sailing o'er life's solemn main,

A forlorn and shipwrecked brother,

Seeing, shall take heart again. 
Let us, then, be up and doing,

With a heart for any fate;

Still achieving, still pursuing,

Learn to labor and to wait. (1.1-12, 17-20, 25-36)

Though, like many of Longfellow's poems, 'A Psalm of Life' has an erudite intertextual connection (it responds to the fifteenth-century Castilian poet Jorge Manrique), this was not visible to most of its readers. 'A Psalm of Life' draws on the Christian hymn and on Biblical allusion without quite being a religious poem, it is not a psalm in praise of God, but a psalm in praise of work. It is also a manifesto for the purpose of poetry. Poems should not deploy 'mournful numbers', which suggests both depressing content and form, they should uplift, they should inspire action. Formally, they should have a steady, encouraging rhythmic beat Longfellow's metre here is the single most important use of trochaic tetrameter in the Victorian period - and in terms of content, they should be encouraging and motivational. 'A Psalm of Life' uses militaristic language to suggest heroism, coded as male though vague enough to apply more broadly, and presents a goal of forward progress, in which every generation's choices and actions will inspire those who come after, even if the purport of these labours is not visible in the present day.

Carolyn Steedman's fine reading of 'A Psalm of Life' notes that it is highly conventional and 'fixed in the sense of cleaving to convention, unfolding predictably', while also being 'unfixed' enough to enable wide interpretations of its meaning. ${ }^{6}$ For many Victorian readers, I would add, Longfellow's poem did not so much cleave to conventions as set those conventions. A widely applicable taxonomy for Victorian and early twentieth century communal inspirational verse can be drawn directly from 'A Psalm of Life'. Firstly, an 'inspirational' poem is one which aims to instil resolution in the reader, to raise their 
spirits. It will emphasize life's difficulties and problems, and focus on gaining the strength to overcome these, with the implication that they can and will be overcome. The message of inspirational verse is thus both pessimistic and optimistic: life is hard, but individuals and collectives have the power to effect change and make forward progress. There is a strong sense of passing the torch onward, leaving 'Footprints on the sands of time' which may in turn inspire another. As in 'A Psalm of Life', this genre of inspirational verse often contains a loosely religious message, though it differs from hymns in that this is unspecific and nonsectarian with few direct mentions of God or Christ. It is almost always written in highly conventional and familiar lyric forms, most commonly 4-line abab tetrameters, with a strong rhythmic beat, usually trochaic, and it is short. Stylistically, it rests on exhortation, and addresses the reader in the second or third person; it will most often use language associated with travel, conflict or battle, and with labour. The language of inspirational verse should be simple, and even in poets who usually work in Scots or English dialect, poems in this category are almost always in standard English.

When such verse is produced by working-class writers for a presumed audience of working-class readers, as in many local newspapers, it follows these norms and takes on some additional characteristics. Firstly, the difficulties the reader (and writer) must overcome are more likely to be identified as poverty, want, hard labour, and ignorance. Secondly, there is a stronger emphasis on masculinity and 'manliness', especially manly labour, as a means to foster courage and resolution: here, this poetry feeds into discourses of muscular Christianity and the dignity of work. Third, there is likely to be greater emphasis on the need for self-help through moral or educational improvement, as well as communal endeavour. And most importantly, the community identified in the poem is often implicitly or explicitly 'we the workers' or 'we the people'. As this last point might suggest, in working-class verse the language of 'inspiration' has not only a religious but a communal political edge. What is vital 
is that this genre was malleable, so that by virtue of its refusal to locate itself in time or place, it becomes adaptable to interpretation via the different contexts in which it is used. This applies both to the ways in which a canonical poet like Longfellow is used by British workers, as discussed below, and to the ways in which they deployed their own efforts at inspirational verse.

Much of this verse is pseudonymous or anonymous, and there is so much of it that any encounter with a Victorian newspaper will produce examples. Several instances by known Victorian working-class writers can serve to typify the whole. James Waddington's 'Lead the Way!', for instance:

Pioneers of human progress,

Gird yourselves in war array,

With a daring heart that dreams not

E'er of shrinking from the fray.

Though your foes strive to retard you

In your marches day by day,

On! Success will crown your efforts.

Lead the way!

Brother men are bound in darkness,

Slaves of ignorance and sin,

Go! and burst the iron fortress,

Let heaven's glorious sunlight in.

Clear the rocks that choke the pathway

Up to knowledge, as ye may

With the torch of truth to guide you 


\section{Lead the way! ${ }^{7}$}

Waddington, who also published as 'Ralph Goodwin' in the Yorkshire and Lancashire press, was a woolsorter in the mills at Saltaire, and part of a local circle of Bradford poets; he died young in 1862. 'Lead the Way!' could be identified as inspirational verse from the title and exclamation mark alone. In terms of the tropes I identify above, it lists the barriers of 'darkness', 'ignorance' and 'sin' and uses military imagery to suggest a means to overcome them. It references 'heaven', yet the 'glorious sunlight' appears to be the light of knowledge, not anything specifically Christian. It speaks to a collective of 'brother men', and to a collective 'you.' It is about progress and a teleological movement upwards and onwards. It uses repeated exhortations and exclamation marks, and the firm beat of the trochaic tetrameter links it to a marching rhythm. In the context of Waddington's status as a Saltaire poet, 'progress' might refer to technological progress, such as that exemplified by Sir Titus Salt's mills, and to the need for intellectual progress to ensure Britain's continued advance, as exemplified by Saltaire itself and Salt's efforts to incorporate 'improving' institutions in his model mill town.

Moving north to the Borders mills, William J. Currie, a millworker and temperance poet (much of the language used in inspirational verse lent itself easily to the temperance cause), produced another typical example in 'Forward - Never Despair':

Toiling brother, strong and hopeful,

Fearless tread the path of life:

Faint or weary, be not driven

From true manhood in the strife.

Courage, brother! Life is worthy

Of our highest, noblest aims; 
Tis no idle dream of fancy,

That our heart's best effort claims

Steady, brother! Be not selfish;

Love must rule us in the fight,

If we would prove truly noble

We must know no aim but Right.

Carping souls may jibe and jeer us

With their words that bitter seem;

Heed them not, but working, show them

"Life is not an empty dream."8

Again, this rests on the language of brotherhood, though it uses the collective 'we' rather than 'you.' It alludes to fighting and strife, to moving forward through conflict on the 'path of life', to the nobility of labour, and it once more uses exclamations and the same marching rhythm to underline its argument about perseverance and courage. The duty of the poet, in poems like Currie's and Waddington's, is to provide readers and listeners with the inspiration to carry on. As Janet Hamilton wrote in her 'Song of the Lowly Bard':

Yet not low my aspiration

High and strong my soul's desire

To assist my toiling brothers

Upward onward to aspire

Upward to the heaven above us

Onward in the march of mind 
Upward to the shrine of freedom

Onward working for our kind ${ }^{9}$

Hamilton supplied a handwritten, autographed copy of this text to James Gould of Glasgow, who collected the works of local poets, in 1863. Poems with this kind of message were the ones that writers thought most appropriate for an autograph book, as a form of calling card. Again, Hamilton's language is familiar: 'toiling brothers', 'march of mind', 'shrine of freedom.' While there may be a gendered dimension to her determination to assist her 'toiling brothers', rather than being one of those brothers, phrases like these are used indistinguishably by male and female poets of the period. They are recognizable from sermons, essays, speeches and multiple other forms of discourse centred on the mid-Victorian culture of improvement and the cult of progress.

The intertextual relationship of these poems to Longfellow is deliberate. Even excluding Currie's direct quote from 'A Psalm of Life' ('Life is not an empty dream'), rhythm, language and rhymes such as 'way/day' or 'life/strife' all echo this poem. By the 1850 s and 1860s, when these poems were produced, Longfellow's short lyrics were household words, and he himself was reaching the height of his international fame. This fame rested on an appeal to the new mass readership, not to the highly literate and well-educated reader. In 1863, the Illustrated London News observed that:

There is no English poet now living how has so many readers in England as Longfellow. His writings are, indeed, known to the million; they find a place on shelf or table in the humblest artisan's home, where Tennyson and Browning have not yet come. $^{10}$

Of course, Longfellow's poems were available to British artisans in a way that Tennyson and Browning were not, because the lack of an international copyright law meant that many more cheap editions of Longfellow were in circulation. ${ }^{11}$ Famous anecdotes, such as that of Queen 
Victoria's surprise at finding out that her staff had heard of Longfellow and that 'many of his poems were familiar to them', cemented the notion that Longfellow was the poet of the people. (cited Irmscher 2006, p.12) Newspapers and periodicals reported widely on Longfellow's life and works and reprinted his poems: as John Morton notes in his consideration of Longfellow's celebrity tour of Britain in 1868, 'Editors of regional newspapers throughout the British isles clearly assumed their readers' interest in Longfellow.' ${ }^{12}$ Newspapers tended to suggest that the reading public had taken Longfellow to heart because of his ability to offer comfort and inspiration in dark times. The Durham Chronicle, typically, suggested that his poems:

come to us when some long-cherished friend is dead, and the great world is empty... where the way grows dark and steep through undeserved failure and defeat: they come to all 'in peace and strife,' - to the humble hearth as the crowding street, pointing beyond the stars to a brighter, happier future. ${ }^{13}$

The Fifeshire Journal, in 1873, nicely indicated the spread of Longfellow's influence by reprinting an article from Scribner's on Longfellow, suggesting that his poems helped to 'remind the embittered, baffled struggler among the waves of life that existence is not entirely shadow and defeat', in the same column as an inspirational poem by local poet James Pringle of Springfield, drawing on tropes popularized by Longfellow:

Man is formed and framed for action, Not in stillness to repose;

Onward, forward, still advancing, Till his days in darkness close. ${ }^{14}$ In conjunction, this poem and article suggest that reviews praising Longfellow's verse and, often, arguing that it was representative of the highest aims that poetry should espouse, might have helped to encourage local poets to follow Longfellow's lead. For the unknown James 
Pringle, producing this very familiar kind of inspirational verse was his best chance of securing a coveted place in the local newspaper's poetry column.

Recent studies focusing on Longfellow's popularity and standing in Britain have not commented in any detail on his influence on working-class writers. ${ }^{15}$ It is important to note, however, that a number of Longfellow's best-known poems had a particular appeal to this audience because they are about work and the worker, including the most famous Victorian equivalent of Robert Burns's 'The Cottar's Saturday Night', 'The Village Blacksmith', and the industrial poem 'The Ropewalk'. In poems like 'The Ladder of St Augustine', Longfellow also writes from the subject position of the 'toilers' he addresses:

The heights by great men reached and kept

Were not attained by sudden flight,

But they, while their companions slept,

Were toiling upward in the night.

Standing on what too long we bore

With shoulders bent and downcast eyes,

We may discern - unseen before -

A path to higher destinies. (1.37-44)

The poet here is not one of the great men, but one of those who has been bearing a heavy load, and is now determining to toil upwards, step by step. Like 'labour' in 'A Psalm of Life', Longfellow uses 'toil' in a broad sense, yet this is language that is easily interpreted as referencing labourers or workers. Longfellow also consciously championed 'lowly' poets in another of his most famous poems 'The Day is Done', where he states that he does not want to hear the work of 'great masters' or 'bards sublime' but the words of 'some humbler poet/Whose songs gushed from his heart': 
Who, through long days of labour,

And nights devoid of ease,

Still heard in his soul the music

Of wonderful melodies. (1.25-6, 27-30)

Longfellow's ability to create an unassuming authorial persona that encouraged readers to think of him as a friend has been well assessed by critics. ${ }^{16}$ It is not at all surprising, reading these lines, that working-class poets in particular saw him as an ally.

Editors and patrons of working-class literature also strongly promoted Longfellow as a model for the aspiring poet. The Glasgow Citizen, reformist in politics and notable for its support of local writers, published five Longfellow poems from 1851-2, including 'The Ladder of St Augustine.' ${ }^{17}$ When tailor-poet James Nicholson won a prize for submissions to Cassell's Working-Man's Friend in 1857-an incident recounted in his prize-winning autobiography in the Glasgow Commonwealth - the prize was two volumes of Longfellow's poems. ${ }^{18}$ Agnes Stuart Mabon, another Borders millworker poet, pictured a local newspaper poet gazing longingly into a bookseller's window, wondering whether to spend his one coin on 'Longfellow, Hogg, or Burns', suggesting that Longfellow had joined the pantheon of essential working-class writers. ${ }^{19}$ It is also one of Longfellow's distinctions that he seems to have been a frequently plagiarized poet (probably the most frequently plagiarized poet) in newspaper poetry competitions, as when the People's Journal noted in 1875 that not one but several competitors had copied and submitted Longfellow's 'The Reaper and the Flowers' as their own work. ${ }^{20}$ Quotations from Longfellow, and especially from 'A Psalm of Life', also become common, from the 1850 s onwards, in any local speech that references self or mutual improvement, such as the talks at a Reform meeting in Keighley in 1867, a speech on the opening of a new temperance hall in Hawick, or at the Bathgate Co-operative Society's Grand Entertainment. ${ }^{21}$ He was toasted alongside Burns at Burns Society events, including a 
Paisley centenary dinner at which Longfellow's poems were cited as 'voices... which proclaim emancipation from the thraldom of some old and chartered conventional ties. ${ }^{22}$

In the final section of this article, I want to turn to inspirational verse that continues to draw on Longfellow's example, but shifts his deliberately vague message of striving, labouring, and working for a better day into political discourse. Inspirational poetry by working-class writers often sits at the intersection between relatively conservative Christian ideology (striving humbly to effect positive change in society and in the self) and a radical political message (fighting to overcome the barriers faced by the working people and to effect societal change), as the language of religious community and the language of political brotherhood intersect. The Miner and Workman's Advocate, for instance, an avowedly protrades union periodical, used Longfellow in a variety of ways over the course of two years (1865-1867). One pseudonymous 'Miner' from Pimbolane (near Wigan, a coal-mining area in Lancashire) deployed 'A Psalm of Life' in a highly sentimental poem about the positive influence of a little child visiting a prisoner, 'Footprints of Love'. It concludes:

Then, little one, go thou,

And do some loving thing;

Leave footprints on the sand of time,

Whence blessed fruits may spring. ${ }^{23}$

This poem seems designed to demonstrate the feeling sympathies of miners and their tender hearts, as well as their ability to write educated verse. It is thus entirely in line with the paper's mission to demonstrate that educational and moral self-improvement, in conjunction with union organization, will help to effect positive change in the industry. Just two weeks before this poem appeared, an editorial on 'Power and Pleasure' had quoted 'Lives of great men all remind us' in an article arguing for the importance of self-improvement and urging 
workers to 'look upward' and 'obtain knowledge'. ${ }^{24}$ A year before this, an editorial on the Mechanics Institute movement and working men's reading rooms concluded:

Press forward - determine to excel in all you undertake - and you will acquire a knowledge of your strength in the social organization of which you are the foundation...Many of you are no strangers to the poetry of Longfellow; there is a verse in his 'Village Blacksmith' that bears on this theme. ${ }^{25}$

As often, editors reach for Longfellow to provide a stirring conclusion to their own rhetoric: note also the assumption here that many of the working men reading The Miner know the poems of Longfellow already.

That this was a fair assumption is supported by the presence of several more explicitly political poems in the paper which rework Longfellow's inspirational verse. 'Lines on the "Excelsior" National Association of Tinplate-Makers', for instance, is a version of Longfellow's 'Excelsior!' which celebrates trades unionism:

No more our neighbour undermine,

But let us one and all combine;

For tyrants long have ruled the day,

But now our banner we must sway -

Excelsior!

Onward, onward, let us go,

We'll face the world and every foe;

And when oppression we subdue,

Our song will be forever new -

Excelsior! 
So hand in hand we'll travel on,

Until the victory we have won;

And when our glorious battle's o'er,

Higher let our banner soar -

\section{Excelsior! $!^{26}$}

The second two stanzas cited here could belong in any instance of inspirational verse, with their familiar message of travelling forward and boldly overcoming unidentified foes. But the title of the poem, and the language of tyranny and combination, make it clear that readers are supposed to be inspired to a specific end: to join a union. Similarly, in a poetry and prose letter complaining about miners' habits of drinking and boasting in the pub, 'W. E.' of Spennymoor (a Durham mining village) concluded:

Then up and let's be doing,

Let us work while it is day,

Don't put off until to-morrow

What must be done to-day.

Foolish customs need reforming,

Let us banish every wrong,

With love and truth united,

We will, we will be strong.

Up, up, then, let's be doing,

Why cavil on the way?

Away with petty differences,

And hail the happy day. 
Man's true liberty's in union.

'Tis a truth well understood;

Then unite in one close brotherhood,

For the universal good. ${ }^{27}$

W. E.'s move from 'tomorrow' to 'to-day' and the rhymes on 'way' and 'day', as well as the tetrameter rhythm, again bring an aural memory of Longfellow into his poem. Words like 'Reforming' are not loose terms in the 1860 s, but have specific reference to Reform and the fight for the extension of the franchise. The 'we' in both these poems is a group of workers in a particular industry, who will overcome wrong not through a generic sense of unity and brotherhood but by signing up to the Union.

This use of the Longfellowian language of inspirational verse in trades unionism remained constant into the last decades of the Victorian period. James (Keir) Hardie, in a letter to the Hamilton Advertiser on 'Miner's Union', used the same Longfellow quotation for the same end nearly twenty years later:

Make the chain of Union stronger,

Binding man to brother man,

Till short time and sweet restriction

Triumph over all the land

Till the miners of this nation,

Bind together firm and sure

Shall throw off their present fetters, Slavery no more endure. 
"Let us then be up and doing

With a heart for any fate

Still achieving, still pursuing,

Learn to labour and to wait." 28

To connect 'A Psalm of Life' and anti-slavery rhetoric is in line with Longfellow's own ideals, since he was a committed abolitionist who wrote a collection of anti-slavery verse. As in most instances where Longfellow is referenced, Hardie did not need to mention his name. It could be assumed that readers recognized the quotation. Quoting Longfellow also serves to highlight Hardie's own cultural capital. His fellow Scottish union activist and miner Robert Smillie, in his autobiography, noted that when he began to work for a mining union he considered it essential to educate himself by reading the great poets; by the time he was an established union leader and nascent politician, the walls of his sitting room were 'hung with portraits of Carlyle, Ruskin, Russell Lowell, Longfellow, Walt Whitman, Burns and Scott, each and all of whom I reckon among my dearest friends. ${ }^{29}$

Northern workers' newspapers of the late nineteenth century continued to display interest in politically-oriented inspirational verse, and in Longfellow as a model for this. Though, as Kirsten Harris has shown, more evidently radical writers such as Whitman were gaining ground in socialist periodical and newspaper culture, the formal influence of Whitman's experimental verse was still relatively small, compared to the persistence of the four-line stanza trochaic tetrameter lyric with inspirational intent. ${ }^{30}$ In Teddy Ashton's Journal (later the Northern Weekly), one of a constellation of 1880s and 1890s Northern papers aimed at an audience of textile workers, contributor R. H. Brodie represented Longfellow to readers as a radical abolitionist, whose anti-slavery poems 'have perhaps done more to bring about the freedom of the slave than the Civil War itself', as the poet of the 'humble man', and as the poet of the worker: 'What calls to arms he sounds to the workers, 
and how he quickens the soul and inspires courage. ${ }^{31}$ This admiration was not necessarily shared by all contributors. One published a deliberately controversial article taking aim at the doctrine of self-help, and parodying Longfellow in order to argue that those who rose from poverty to wealth seldom moved to help others:

Lives of great men all remind us,

How to rise from fair to fine,

And to leave the poor behind us

Stranded on the sands of time. ${ }^{32}$

Yet Teddy Ashton's Journal and its sister papers, the Cotton Factory Times and the Yorkshire Factory Times, also included a high number of poems showing a continued debt to Longfellow, such as 'A Psalm of Labour' by the anonymous ' $\mathrm{H}$ ', from the Yorkshire Factory Times:

Tell me not in scornful numbers,

Workers still should be your slaves;

They are rousing from their slumbers,

And for freedom each one craves.

The poem goes through nine of Longfellow's stanzas, rewriting each one, and ending:

Honest toilers, help each other,

Sailing o'er life's solemn main;

All unkindly feelings smother,

Trying heaven on earth to gain.

Working men, be up and doing,

To this good cause be ye true:

Justice, truth, and right pursuing, 
Labour's cause keep aye in view. ${ }^{33}$

Though the author is to some extent cynical about Longfellow's message, commenting that the labourers 'can't make our lives sublime' while wealth and capital triumph, this is still inspirational verse, urging solidarity, action, forward progress, and determination to overcome difficulties.

Many poems in the Yorkshire Factory Times's poetry column, like the earlier poems from The Miner and Workman's Advocate, share this aim to inspire workers both with feelings of righteous indignation and with the will to act on this indignation, generally by joining a union. Others reach for a broader sense of Christian resolution, as in Sarah Ann Robinson's 'The Real Soldiers':

There is beauty all around us

When the hand of toil is near;

Onward, upward you are going, While you harden all things here. ${ }^{34}$

'Onward', 'upward', 'toil', movement and progress: Robinson's poem is nearindistinguishable from Hamilton's, three decades earlier. But it is the publishing context, in a poetry column which specifically existed to publish poems on the theme of 'Labour, work and workmen, or companion topics' which has changed. ${ }^{35}$ Robinson, a weaver from Padiham, was a longstanding poetic contributor to the Yorkshire Factory Times and also associated, as an occasional contributor and writer for children, with Teddy Ashton's Journal. ${ }^{36}$ Regular readers knew that she published first-person poems identifying herself as an exhausted and exploited power-loom weaver, and even occasional readers knew that including the signature 'Padiham', a Lancashire weaving town, was a way of identifying the author as a Lancashire millworker. When Robinson speaks of 'us' and 'our' then, she specifically references textile workers (male and female, though some of her poems deal 
explicitly with gendered issues in the factory); when she writes of 'toil', readers know that she references her - and their - form of labour.

Many of the working-class poets cited here were active in churches, temperance movements, or both, and their language of inspiration draws heavily on this context and on the work of popular hymns and hymn-writers, such as Sabine Baring-Gould's 'Onward, Christian soldiers!'. But in terms of tracing literary influences on the form and language of their poems, and in identifying which canonical poets were most commonly referenced in workers' newspapers and magazines throughout this period, Longfellow markedly stands out. Newspaper and periodical database searches cannot fully represent this influence, partly because many British workers' periodicals are not digitized, but primarily because his works were so well-known that his name or the title of his poems did not need to be given. His presence, appropriately for a poet who was deeply interested in echoes and hauntings, is evident in formal and linguistic signals that do not always reach the level of direct quotation or adaptation.

Recognizing Longfellow's contribution to British working-class literature is significant in itself, as it suggests a broader underestimation of the transatlantic interests of working-class readers. As I have discussed elsewhere in relation to Burns's influence on working-class writers, studying the poems above also shows us working-class writers not as imitators but - in the language of fan studies - as creators of transformative works, producing versions of Longfellow for an audience of fans very familiar with the canon. ${ }^{37}$ Rewriting Longfellow's inspirational poems for political ends - trades unionism, Labour activism, socialism - can thus be a means of critiquing their malleability and refusal to lay out a political position, as well as capitalizing on it. But Longfellow's influence also highlights the need to reconsider the role of inspirational verse in working-class poetics. In 1892, the 
Yorkshire Factory Times published an article on 'The People's Poetry' by regular contributor 'Simeon Twigg', which commented:

Who among the people cares for Swinburne, with his dashing, swinging, lounging measures, and his curious, involved conceits? Or for Arnold, whose work has been so much belauded by pressmen ambitious to show their knowledge? And even among Tennyson's poems how few there are that stand out prominently as people's favourites! $!^{38}$

The reason these canonical poets had not found universal favour, the writer argued, was because they were not writing simply enough or movingly enough. Popular poems should 'touch the little griefs of the people, and the hearts of the people will beat responsive to them', and to enable this, they should not contain 'a word that the people cannot understand'. They should also rhyme. The author of this article, James Bartley, an Irish printer living in Bradford and very active in the socialist and trades union movements, argues for a revaluation of the 'little' in poetry, and a recognition that the poems that are most useful for working people are found in newspaper poetry columns, not in the books of established and highly-educated poets. This use value is predominantly affective. Inspirational poetry 'comes to us' in times of trouble. Its steady marching rhythms and firm rhymes are a support, and a prop, its encouraging language offers hope to the individual, via a sense that their feelings are not unique. This is not just because the poet shares those feelings, but because the poem is embedded in a long-standing tradition of inspirational verse, indicating the commonality of those feelings across generations.

Inspirational verse was a favoured genre for Victorian working-class poets for practical reasons: it is marketable in any context, it is easy to recreate, it will suitably impress employers, editors, and patrons. But we should not overlook, in the prevalence of such verse, and in the ways in which it is shared and reproduced, the desire both to comfort and motivate 
others. And rather than being intended as a panacea which would make 'the people' more content with the status quo, in the hands of founding members of the Labour party and a great many Victorian and early twentieth-century union, suffragette and other activists, this motivation was perceived as a force to produce change. Whether poems such as 'Be Up and Doing', by Ben Turner, Yorkshire Factory Times journalist and Labour party activist and MP, genuinely inspired readers to 'lead on through the darkness, burrow out into the light' (by joining the Labour party) is impossible to prove. ${ }^{39}$ The moment when no-one needed to ask 'What does that even mean?' of 'Excelsior!', because everyone shared a presumed understanding of the 'onward and upward' mission the phrase inspired, would not last beyond the mid-twentieth century, at latest. But the fact that Turner, like Keir Hardie, thought it part of his political mission to be able to write 'up and doing' poems, indicates the high status that the Victorian inspirational verse tradition continued to hold, in culture, society and politics, into that century. 


\begin{abstract}
${ }^{1}$ Maggie Steifvater, The Raven Boys (London: Scholastic, 2012), pp.51, 400.Henry Wadsworth Longfellow, 'Excelsior,' 1.1-5, from Poems and Other Writings, ed. J. D. McClatchy (New York: Library of America, 2000), p.22. All further references are to this edition and will be given in the text.

2 'Review: Longfellow's Poetical Works, Longfellow's Poems', The Star of Freedom, 22 May 1852, p.3. The review includes 'Excelsior' and 'The Psalm of Life' in entirety. Paul Thomas Murphy briefly comments on the support for American poets, including Longfellow, in the Chartist press, which held them up as exemplars of democracy and representatives of the abolitionist cause (Toward a Working-Class Canon: Literary Criticism in British Working-Class Periodicals, 1816-1858 (Columbus: Ohio State University Press, 1994), pp.125-6).

${ }^{3}$ The most notable account of the popularity of 'Excelsior' in American culture is in Christoph Irmscher, Longfellow Redux (University of Illinois Press, 2006), pp.61-66. For the Excelsior MS magazine, held in Liverpool Record Office, see http://www.literarybonds.org/periodicals/the-excelsior-manuscript-magazine/ [consulted 1.9.20]. The Southern and Western Textile Excelsior was published from Charlotte, N.C. from 18901921. It was occasionally quoted in the British textile workers' newspapers e.g. Yorkshire Factory Times, 27
\end{abstract} August 1897.

${ }^{4}$ For example, Caley Ehnes, Victorian Poetry and the Poetics of the Literary Periodical (Edinburgh: Edinburgh UP, 2019), especially chapter 4 on devotional reading; F. E. Gray's Christian and Lyric Tradition in Victorian Women's Poetry (New York: Routledge, 2010); Kathryn Ledbetter, British Victorian Women's Periodicals: Beauty, Civilization, and Poetry (Houndmills: Palgrave Macmillan, 2009). Catherine Robson's Heart Beats: Everyday Life and the Memorized Poem (New Jersey: Princeton UP, 2021) perhaps comes closest to examining the emotional impact of inspirational verse on readers who memorized poems in an educational environment: she notes Longfellow's importance in classrooms as an 'improving' poet (e.g. p.35). Matthew Campbell's Rhythm and Will in Victorian Poetry (Cambridge: CUP, 1999) and its focus on formal efforts to represent a Carlylean 'ideology of resilience and activity' (p.3) is also significant in relation to the attempts of inspirational verse to instil this resilience in readers.

${ }^{5}$ For a good account of intertextuality in 'A Psalm of Life', see Andrew Higgins, 'Longfellow's Conversations: Weltliteratur as Aesthetic in the Early Poetry' in Reconsidering Longfellow, ed. Christoph Irmscher and Robert Arbour (New Jersey: Fairleigh Dickinson University Press, 2014), pp.11-32.

${ }^{6}$ Carolyn Steedman, Strange Dislocations: Childhood and the Idea of Human Interiority, 1780-1930 (Cambridge MA: Harvard University Press, 1998), pp.25, 31. 
${ }^{7}$ James Waddington, 'Lead the Way!', in Flowers from the Glen: The Poetical Remains of James Waddington of Saltaire, ed. Eliza Craven Green (Bradford: Abraham Holroyd, 1862), pp.55-6.

${ }^{8}$ William J. Currie, 'Forward - Never Despair', in Doric Lilts: A Selection of Songs and Poems on Temperance and Other Subjects (Galashiels: John McQueen, nd), p.7.

${ }^{9}$ Janet Hamilton, 'Song of the Lowly Bard'. I take this transcript from the autograph copy in Stray Green Leaves: A Collection of Poems and Songs by Known and Unknown Authors Extracted from the Newspapers with Holograph Poems and Select Pieces Published Previous to 1860. Collected by James Gould. Mitchell Library, Glasgow. REF SR 193. Hamilton's poem is dated October 1863.

10 'The Poet Longfellow', Illustrated London News, 17 July 1869, p.18.

${ }^{11}$ See Simon Eliot, 'What Price Poetry? Selling Wordsworth, Tennyson, and Longfellow in Nineteenth and early Twentieth-Century Britain' Papers of the Bibliographical Society of America 100.4 (2006), 425-445. Eliot describes Longfellow as 'one of the most affordable' contemporary poets in terms of book prices.

${ }^{12}$ John Morton, 'Longfellow, Tennyson, and Transatlantic Celebrity', Critical Survey 27:3 (2015) 6-23 p.17.

13 'Longfellow's Poems', Durham Chronicle, 29 April 1853, p.3.

${ }^{14}$ James Pringle, 'Happiness', and ‘An American Estimate of Longfellow', Fifeshire Journal, 27 November 1873, p.3. Pringle signs his poem from Springfield, a Fife village associated with the linen industry.

${ }^{15}$ Irmscher (2006) remains the most extensive discussion of Longfellow's international popularity, though with the greatest focus on American readers and fans. He does note Longfellow's influence on amateur poets and the way in which his poems champion 'the merits of the average talent in poetry.' (p.68) Morton and David Haven Blake's, 'Among the English Worthies: Longfellow and the Campaign for Poets' Corner', Critical Survey 27.3 (2015), 82-104 both establish the case for Longfellow's immense popularity with British readers.

${ }^{16}$ See, for example, Kirsten Silva Gruesz, 'Feeling for the Fireside: Longfellow, Lynch, and the Topography of Poetic Power', in Sentimental Men: Masculinity and the Politics of Affect in American Culture, ed. Mary Chapman and Glen Hendler (Berkeley: University of California Press, 1999), pp.43-63

${ }^{17}$ Three of the five poems were 'The Ladder of St Augustine', Glasgow Citizen, 18 January 1851, p.4; 'The Rainy Day', Glasgow Citizen, 23 August 1851, p.4; 'Twilight', Glasgow Citizen, 31 July 1852, p.4.

18 'The Life of Jacob Holkinson, Tailor and Poet, III', Commonwealth, 31 January 1857, p.3. Nicholson identifies himself as the author of this autobiography in his later works.

${ }^{19}$ Agnes Stuart Mabon, 'The Local Poet', Homely Rhymes, from the Banks of the Jed (Paisley: J. and R. Parlane, 1887), p.40. 
${ }^{20}$ Editorial note on Christmas poetry competition, People's Journal, 18 December 1875, p.2.

${ }^{21}$ Keighley News, 19 January 1867, p.2; Hawick Express, 13 December 1879, p.4; West Lothian Courier, 19 February 1881, p.2.

${ }^{22}$ Angus MacPherson, toast to Longfellow, 'Celebration of the Centenary of the Birth of Robert Burns, the National Bard of Scotland, in Paisley,' Paisley and Renfrewshire Advertiser, 29 January 1859, p.1.

23 'A Miner', 'Footprints of Love', The Miner and Workman's Advocate, 4 February 1865, p.6. This poem is also alluding to Longfellow's 'Footsteps of Angels'.

24 'Power and Pleasure', The Miner and Workman's Advocate, 21 January 1865, p.4.

25 'Mechanics' Institutions, Working-Men's Reading Rooms, and Education', The Miner and Workman's Advocate, 9 January 1864, p.4.

${ }^{26}$ W., 'Lines on the "Excelsior" National Association of Tinplate Makers', The Miner and Workman's Advocate, 6 February 1864, p.8.

${ }^{27}$ W. E., Spennymoor, letter to editor, The Miner and Workman's Advocate, 16 January 1864, p.7.

${ }^{28}$ James Hardie, 'Miners’ Union', Hamilton Advertiser, 29 May 1880, p.2.

${ }^{29}$ Robert Smillie, My Life for Labour (London: Mills \& Boon, 1924), p.53

${ }^{30}$ Kirsten Harris, Walt Whitman and British Socialism: The Love of Comrades (New York: Routledge, 2016).

${ }^{31}$ R. H. Brodie, 'Longfellow - An Appreciation', Northern Weekly, 19 April 1902, p.2. The Northern Weekly was the rebranded Teddy Ashton's Journal, founded in 1896 by Charles Allen Clarke. Clarke was also heavily involved, under his various literary pseudonyms, with the Cotton Factory Times and the Yorkshire Factory Times.

32 'Roving', 'Labourers and Talent', Teddy Ashton's Journal, 20 August 1898, p.2.

${ }^{33}$ H., 'A Psalm of Labour', Yorkshire Factory Times, 18 March 1892, p.2.

${ }^{34}$ Sarah A. Robinson, 'The Real Soldiers', Yorkshire Factory Times, 7 October 1898, p.2.

${ }^{35}$ Editorial note below 'Original Poetry’ column, Yorkshire Factory Times, 1 January 1892, p.2.

${ }^{36}$ See Kirstie Blair, 'Sarah Ann Robinson, Working-Class Women's Poetry, and the Yorkshire Factory Times', History Workshop Online, February 2020: https://www.historyworkshop.org.uk/sarah-ann-robinson-workingclass-womens-poetry-and-the-yorkshire-factory-times/ [consulted 1/9/20]

${ }^{37}$ Blair, 'No new note? Burns and the Victorian Working-Class Poet', in The Oxford Handbook of Robert Burns (forthcoming 2022).

38 ‘The Errand Boy', 'The People's Poetry', Yorkshire Factory Times, 29 January 1892, p.1. 
${ }^{39}$ Ben Turner, from 'Be Up and Doing', in Dialect and Other Pieces from a Yorkshire Loom (Heckmondwike: Senior \& Co, 1909), p.86. Turner was General President of the General (later National) Union of Textile Workers from 1902-1933, a founder member of the Independent Labour Party, and became a Labour MP in 1922. 